\title{
Effect of Nitric Oxide on $\beta$-Glucan/Indomethacin-Induced Septic Shock
}

\author{
Sachiko Nameda, Maki Saito, Noriko N. Miura, Yoshiyuki Adachi, and Naohito Ohno* \\ Laboratory for Immunopharmacology of Microbial Products, School of Pharmacy, Tokyo University of Pharmacy and Life \\ Science; 1432-1 Horinouchi, Hachioji, Tokyo 192-0392, Japan. \\ Received January 12, 2005; accepted April 12, 2005; published online April 21, 2005
}

\begin{abstract}
We have previously shown that repeated administration of nonsteroidal anti-inflammatory drugs (NSAIDs) to mice treated with $\beta$-glucan, a biological response modifier, induced severe lethality. The lethality would be strongly related to the translocation of enterobacterial flora to the peritoneal cavity and disruption of the cytokine network. Reports suggest that nitric oxide (NO) can have an effective or detrimental role in septic shock. In the present study, we examined the effect of NO, an inflammatory mediator, on $\boldsymbol{\beta}$-glucan/indomethacin (IND)induced septic shock by inhibiting its synthesis with $N^{\mathrm{G}}$-nitro-L-arginine methyl ester (L-NAME), a nonselective NO synthase (NOS) inhibitor. Nitrite concentration was used as an indicator of NO generation. Mortality in $\beta$ glucan/IND-treated mice was increased by administering L-NAME. Numbers of bacteria in various organs of mice treated with $\beta$-glucan/IND rose significantly within a couple of days of the administration of L-NAME. Additionally, TNF- $\alpha$, IL-1 $\beta$, and IL-6 concentrations were enhanced in peritoneal exuded cells in culture. These results suggest a significant loss of the bactericidal activity of macrophages on the administration of a NOS inhibitor which enhanced the rate of enterobacterial invasion to the peritoneal cavity, resulting in systemic inflammatory response syndrome. The production of NO, therefore, provides a protective effect in $\beta$-glucan/IND-induced sepsis.
\end{abstract}

Key words nitric oxide; $\beta$-glucan; indomethacin; bactericidal activity; $N^{\mathrm{G}}$-nitro-L-arginine methyl ester (L-NAME)

Nitric oxide (NO) is an important defense molecule in the nonspecific immune system of the body. ${ }^{1,2)}$ However, NO also acts as a mediator of tissue damage in inflammatory diseases. ${ }^{3)} \mathrm{NO}$ is a highly reactive molecule that is normally produced from L-arginine by NO synthase (NOS). There are three isoforms of NOS: neuronal NOS (nNOS), endothelial NOS (eNOS), and inducible NOS (iNOS). nNOS and eNOS are constitutively expressed, whereas iNOS expression is induced by stimuli such as lipopolysaccharide (LPS) and cytokines. ${ }^{4,5}$ Large amounts of NO produced by iNOS have been shown to play a major role in sepsis and endotoxin shock. ${ }^{6}$

Septic shock is characterized by a systemic inflammatory response syndrome. Sepsis associated with multiple organ failure and dysfunction, leads to hypotension. ${ }^{7} \mathrm{NO}$ is a strong mediator of vasodilation. ${ }^{8)}$

During the last decade, NO has been demonstrated to have a role in septic shock in both humans and experimental animals. ${ }^{9-11)}$ NOS inhibitors have been used to treat septic shock. Indeed, it was reported that a NOS inhibitor restored hypotension in sepsis, but also had a detrimental effect. ${ }^{12-14)}$ Thus, the role of NO in septic shock has not been clarified. The apparent complexity of NO inhibition may be due in part to the different models of sepsis used. Generally, LPS is used to induce septic shock, however, it can not reproduce both gram-positive and -negative sepsis. We developed an animal model of sepsis in mice using two drugs, indomethacin (IND) and $\beta$-glucan, sonifilan (SPG). This model uses endogenous LPS which is contained in enteric bacterial flora.

We have previously examined the activities of various $\beta$ glucans ${ }^{15-19)}$ and found that pretreatment with $\beta$-glucan significantly increased mortality on the subsequent administration of IND in mice. ${ }^{20-23)}$ The lethality would be closely related to the translocation of enterobacterial flora to the peritoneal cavity. Since the concentrations of IFN- $\gamma$, IL- 6 , and CSF in sera of $\beta$-glucan/IND-treated mice were significantly elevated, the mortality was likely due to a mal-adjustment of the cytokine network. A precise characterization of this model is needed to clarify the mechanism of septic shock. In this study, we examined the effect of $\mathrm{NO}$ on this model by inhibiting the synthesis of NO with a NOS inhibitor.

\section{MATERIALS AND METHODS}

Animals Male ICR mice between 5 and 8 weeks of age were purchased from Japan SLC, Inc., Shizuoka and maintained under specific pathogen-free conditions. The breeding and handling of all animals in this experiment were approved by the Committee on Animal Experiments of the School of Pharmacy, Tokyo University of Pharmacy and Life Science.

Reagents Sonifilan (SPG) was purchased from Kaken Pharmaceutical Co. (Tokyo, Japan). $N^{\mathrm{G}}$-nitro-L-arginine methyl ester (L-NAME), aminoguanidine (AG) and indomethacin (IND) were obtained from Wako Pure Chemical Ind. IND was suspended with $2 \%$ polyoxyethylene (20) sorbitan monooleate in $0.5 \%$ sodium carboxymetyl cellulose (CMC).

Administration of SPG/Indomethacin and NOS Inhibitor SPG $(100 \mu \mathrm{g} /$ mouse $)$ dissolved in physiologic saline was administered intraperitoneally to ICR mice every other day a total of three times (day-5, -3 , and -1). IND (2.5, $5 \mathrm{mg} / \mathrm{kg})$ was administered orally and L-NAME $(10 \mathrm{mg} / \mathrm{kg})$ or $A G(15 \mathrm{mg} / \mathrm{kg})$ was administered intraperitoneally daily from day 0 for $14 \mathrm{~d}$. The survival of the mice was monitored.

Assay for Nitrite After incubation for $24-48 \mathrm{~h}$, the synthesis and release of NO by leukocytes were evaluated by assaying the culture supernatant for nitrite. Briefly, $50 \mu \mathrm{l}$ of supernatant was reacted for $10 \mathrm{~min}$ at room temperature with an equal volume of Griess reagent (1\% sulfanilamide, $0.1 \%$ naphthylethylene diamine dihydrochloride, and $2.5 \%$ phosphoric acid). The optical density was measured at $550 \mathrm{~nm}$ 
(Ref. $630 \mathrm{~nm}$ ). The nitrite content was quantified by comparison with a standard curve generated with sodium nitrite at concentrations in the range of $0-100 \mu \mathrm{M}$.

Bacterial Numbers in Various Organs Groups of mice were sacrificed on day $2-6$. Various organs (peritoneal cavity, liver, spleen, lung, and heart) were collected. Each organ was placed in cold sterile phosphate-buffered saline. The samples were homogenized, diluted, and spread on dishes of nutrient agar. The dishes were cultured for $24 \mathrm{~h}$ at $37^{\circ} \mathrm{C}$. The colonies were enumerated by visual inspection.

Cell Culture Peritoneal exuded cells (PEC) collected from mice of each group were counted with a hemocytometer. The cells were maintained in RPMI-1640 medium supplemented with gentamycin sulfate $(5 \mu \mathrm{g} / \mathrm{ml})$ containing $10 \%$ heat inactivated fetal calf serum (FCS), and incubated for $24-48 \mathrm{~h}$ at a density of $1 \times 10^{6}$ cells $/ \mathrm{ml}$ in $5 \% \mathrm{CO}_{2}$ incubator at $37^{\circ} \mathrm{C}$. After the incubation, culture supernatants were collected by centrifugation at $1200 \mathrm{rpm}$ for $5 \mathrm{~min}$.

ELISA IL-6: A 96-well plate (Sumitomo Bakelite Co., Tokyo) was coated with rat anti-mouse IL-6 monoclonal antibody (mAb) (Pharmingen, CA, U.S.A.) in bicarbonate buffer $(\mathrm{pH} 9.5)$ by incubation at $4{ }^{\circ} \mathrm{C}$ overnight. The plate was washed with phosphate-buffered saline (PBS) containing 0.05\% Tween 20 (Wako Pure Chemical Industries) (PBST) and blocked with $0.5 \%$ bovine serum albumin (Sigma) (BPBST) at $37^{\circ} \mathrm{C}$ for $40 \mathrm{~min}$. After another wash, the plate was incubated with recombinant mouse (rm) IL-6 (Pharmingen) or $50 \mu \mathrm{l}$ of sample at $37^{\circ} \mathrm{C}$ for $40 \mathrm{~min}$. It was then washed with PBST treated with biotinylated rat anti-IL$6 \mathrm{mAb}$ (Pharmingen) at $37^{\circ} \mathrm{C}$ for $40 \mathrm{~min}$, before being treated with peroxidase-conjugated streptavidine (Pharmingen) at $37^{\circ} \mathrm{C}$ for $40 \mathrm{~min}$ and developed with a TMB substrate system (KPL Inc., MD, U.S.A.). Color development was stopped with $1 \mathrm{~N}$ phosphoric acid and the optical density was measured at $450 \mathrm{~nm}$.

TNF- $\alpha$ : A 96-well Nunc plate was coated with rat antimouse TNF- $\alpha$ mAb (Pharmingen) in phosphate buffer ( $\mathrm{pH}$ 6) by incubation at $4{ }^{\circ} \mathrm{C}$ overnight. The plate was washed with PBST and blocked with BPBST at room temperature (RT) for $2 \mathrm{~h}$. After further washing, the plate was incubated with rm-TNF- $\alpha$ (Pharmingen) or $50 \mu \mathrm{l}$ of sample at RT for $3 \mathrm{~h}$. It was then washed with PBST and treated with biotinylated rat anti-TNF- $\alpha$ mAb (Pharmingen) at RT for $1 \mathrm{~h}$. After another wash, the plate was treated with peroxidase-conjugated streptavidine (Pharmingen) at RT for $30 \mathrm{~min}$ and developed with a TMB substrate system (KPL Inc.). Color development was stopped with $1 \mathrm{~N}$ phosphoric acid and the optical density was measured at $450 \mathrm{~nm}$.

IL-1 $\beta$ : Culture supernatants were measured using OptEIA (Pharmingen) according to the manufacturer's instructions.

Measurement of GOT and GPT Sera were measured using a GO and GP transaminase kit (Sigma) according to the manufacturer's directions.

Sensitivity of SPG/IND/L-NAME-Administered Mice to LPS LPS ( $1 \mu \mathrm{g} /$ mouse E. coli. O111) was administered i.v. on day 1 . After $1,1.5$, and $2 \mathrm{~h}$ of LPS treatment, sera were prepared.

Statistics Statistical significance was analyzed with Student's $t$-test.

\section{RESULTS}

Production of Nitrite by PEC from Mice Administered SPG and IND We first investigated the concentration of $\mathrm{NO}$, an inflammatory mediator whose production is generally induced in sepsis. The synthesis and release of NO by leukocytes were evaluated by assaying the culture supernatant for nitrite. Briefly, SPG (100 $\mu \mathrm{g} / \mathrm{mouse})$ was administered intraperitoneally to ICR mice every other day a total of three times (day-5, -3 , and -1$)$. IND $(5 \mathrm{mg} / \mathrm{kg})$ was administered orally daily from day 0 to 4 . On day 4 , the mice were sacrificed and PEC were collected. Cell suspensions were adjusted to $1 \times 10^{6} / \mathrm{ml}$ in RPMI-1640 medium containing $10 \%$ FCS and incubated for $24-48 \mathrm{~h}$. After the incubation, the supernatant was collected and the concentration of nitrite in the culture supernatant was determined using Griess reagent. We have reported that SPG has no effect on the production of $\mathrm{NO}$ in vivo or in vitro. However, as shown in Fig. 1, the mice administered SPG and IND produced a significant concentration of NO.

Effect of NOS Inhibitors on Toxicity of SPG and IND To examine the effect of NO on the lethality induced by a combination of SPG and IND $(5 \mathrm{mg} / \mathrm{kg})$ in mice, L-NAME $(10 \mathrm{mg} / \mathrm{kg})$ was administered intraperitoneally daily from day 0 . None of the mice died when only L-NAME was administered (data not shown). As shown in Fig. 2, L-NAME increased the mortality in SPG/IND-treated mice. However, it had a similar effect in the IND-administered mice. To confirm the influence of SPG, the dose of IND was reduced from $5 \mathrm{mg} / \mathrm{kg}$ to $2.5 \mathrm{mg} / \mathrm{kg}$ and the effect compared to that of $\mathrm{L}-$ NAME. It is of note that only the administration of L-NAME

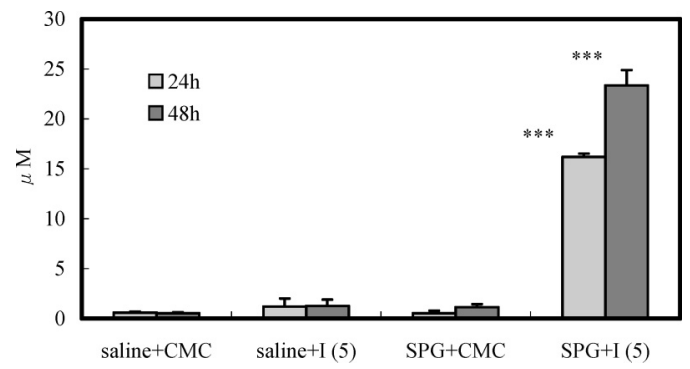

Fig. 1. Production of Nitrite by PEC from Mice Administered SPG and IND

SPG $(100 \mu \mathrm{g} / \mathrm{mouse})$ was administered i.p. 3 times on day-5, -3 and -1 . Indomethacin (IND; $5 \mathrm{mg} / \mathrm{kg}$ ) was administered p.o. from day 0 to 4 . Peritoneal exuded cells (PEC) were prepared on day 4 and incubated for $24 \mathrm{~h}$ or $48 \mathrm{~h}$ at $37{ }^{\circ} \mathrm{C}$ in $5 \% \mathrm{CO}_{2}$. Nitrite production was measured with Griess regent. Results are shown as the mean \pm S.D. The singnificance was evaluated with Student's $t$-test relative to the indomethacingroup. $* * * p<0.001$.

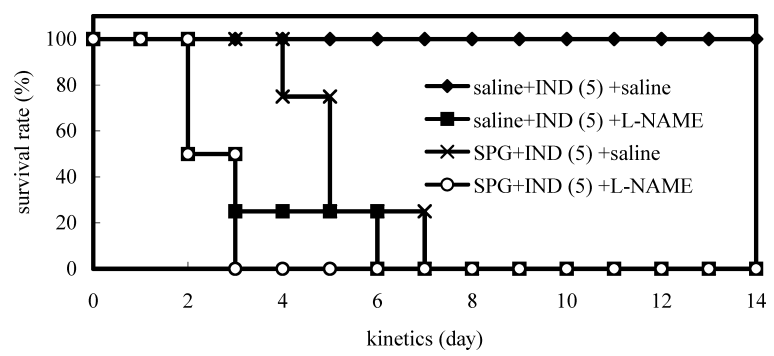

Fig. 2. Effect of L-NAME on Toxicity of SPG/IND $(5 \mathrm{mg} / \mathrm{kg})$

SPG $(100 \mu \mathrm{g} /$ mouse) was administered i.p. 3 times on day-5, -3 , and -1 . Indomethacin (IND; $5 \mathrm{mg} / \mathrm{kg}$ ) was administered p.o. and L-NAME $(10 \mathrm{mg} / \mathrm{kg})$ was administered i.p. once a day from day 0 to 14 and mortality was monitored. 


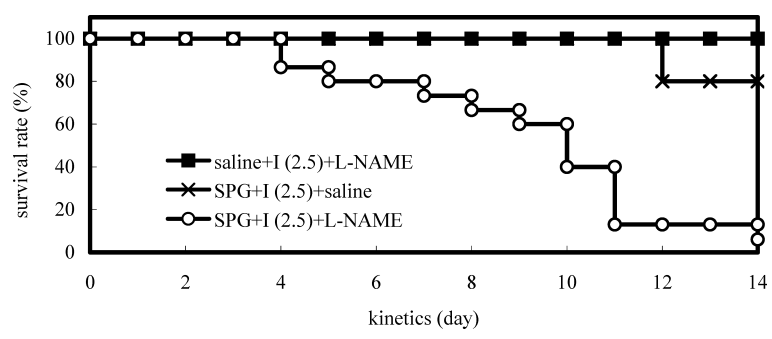

Fig. 3. Effect of L-NAME on Toxicity of SPG/IND $(2.5 \mathrm{mg} / \mathrm{kg})$

SPG $(100 \mu \mathrm{g} /$ mouse $)$ was administered i.p. 3 times on day-5, -3 , and -1 . Indomethacin (IND; $2.5 \mathrm{mg} / \mathrm{kg}$ ) was administered p.o. and L-NAME $(10 \mathrm{mg} / \mathrm{kg})$ was administered i.p. once a day from day 0 to 14 and mortality was monitored.

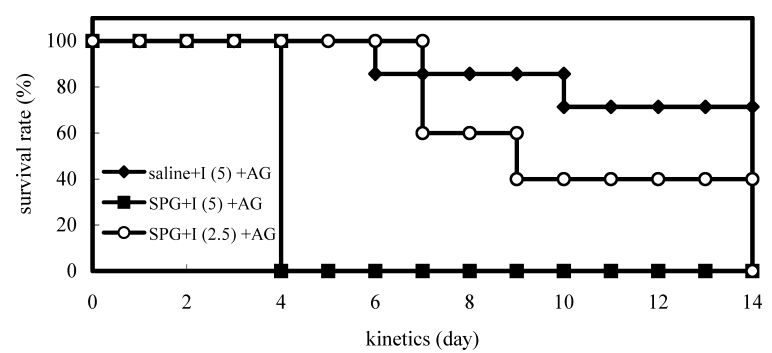

Fig. 4. Effect of Aminoguanidine on Toxicity of SPG/IND

SPG $(100 \mu \mathrm{g} /$ mouse $)$ was administered i.p. 3 times on day-5, -3 , and -1 . Indomethacin (IND; $2.5,5 \mathrm{mg} / \mathrm{kg}$ ) was administered p.o. and aminoguanidine (AG; $15 \mathrm{mg} / \mathrm{kg}$ ) was administered i.p. once a day from day 0 to 14 and mortality was monitored.

to SPG/IND-treated mice significantly increased mortality (Fig. 3). Similarly, administration of AG $(15 \mathrm{mg} / \mathrm{kg})$, a relatively selective inhibitor for iNOS, to SPG/IND treated mice enhanced the mortality (Fig. 4). These results strongly suggested that NO has a protective role in this model.

Bacterial Translocation to Organs NSAIDs are associated with a number of adverse side effects, the most important being mucosal damage in the gastrointestinal tract. The damage induces lethal toxicity and is related to bacterial translocation. To assess bacterial translocation and colonization, we examined the colonization of the peritoneal cavity, liver, spleen, lung and heart. SPG was administered intraperitoneally every other day a total of three times. From day 0 , IND $(2.5 \mathrm{mg} / \mathrm{kg})$ was administered orally and L-NAME or saline were injected intraperitoneally every day. Groups of mice were sacrificed on day $2-6$ and various organs were collected. Each organ was homogenized, diluted, and spread on dishes of nutrient agar. The dishes were cultured for $24 \mathrm{~h}$ at $37^{\circ} \mathrm{C}$. As shown in Table 1, SPG/IND-L-NAME-administered mice contained significantly higher numbers of bacteria than SPG/IND-saline-treated mice in various organs. The bacteria were also detected in blood (data not shown). It suggested that severe damage and increased permeability of the gastrointestinal tract led to ulcers, inflammation of multiple organs and sepsis on administration of L-NAME.

Effect of L-NAME on Cytokine and Nitrite Syntheses of PEC from SPG/IND-Administered Mice To examine cytokine and nitrite levels, SPG/IND-L-NAME-, or -salinetreated mice were sacrificed and PEC were collected on day 6. Cell suspensions were adjusted to $1 \times 10^{6} / \mathrm{ml}$ in RPMI1640 medium containing $10 \%$ FCS and incubated for $24 \mathrm{~h}$. After the incubation, the supernatant was collected. Cytokine concentrations in the resulting supernatants were determined by ELISA (Fig. 5). Treatment with L-NAME and SPG/IND

Table 1. Bacterial Translocation to Various Organs

\begin{tabular}{|c|c|c|c|c|c|c|}
\hline & & \multicolumn{5}{|c|}{$\begin{array}{c}\text { Bacteria positive mouse No./total } \\
\text { mouse No. }(1000< \\
\text { colonies } / \text { mouse })\end{array}$} \\
\hline & & PEC & SPL & Liver & Lung & Heart \\
\hline \multirow[t]{3}{*}{$\mathrm{SPG}+\mathrm{I}(2.5)+$ saline } & Day 2 & $0 / 2$ & $0 / 2$ & $0 / 1$ & $0 / 1$ & $0 / 1$ \\
\hline & Day 5 & $0 / 2$ & $0 / 2$ & n.d. & n.d. & n.d. \\
\hline & Day 6 & $0 / 4$ & $0 / 4$ & $0 / 3$ & $0 / 3$ & $0 / 3$ \\
\hline \multirow[t]{3}{*}{$\mathrm{SPG}+\mathrm{I}(2.5)+\mathrm{L}-\mathrm{NAME}$} & Day 2 & $0 / 3$ & $0 / 3$ & $0 / 2$ & $0 / 2$ & $0 / 2$ \\
\hline & Day 5 & $1 / 3$ & $1 / 3$ & $1 / 1$ & $0 / 1$ & $0 / 1$ \\
\hline & Day 6 & $3 / 4$ & $2 / 4$ & $2 / 4$ & $2 / 4$ & $2 / 4$ \\
\hline
\end{tabular}

SPG $(100 \mu \mathrm{g} /$ mouse $)$ was administered i.p. 3 times on day-5, -3 , and -1 . Indomethacin (IND; $2.5 \mathrm{mg} / \mathrm{kg}$ ) was administered p.o. and L-NAME $(10 \mathrm{mg} / \mathrm{kg})$ was administered i.p. once a day from day 0 to 6 . Groups of mice were sacrificed on day $2-6$. Various organs (peritoneal cavity, liver, spleen, lung, and heart) were collected. Each organ was homogenized, diluted, and spread on dishes of nutrient agar. The dishes were cultured for $24 \mathrm{~h}$ at $37^{\circ} \mathrm{C}$. The colonies were enumerated by visual inspection. Results are shown as the number of positive mice $(1000<$ colonies/mouse).

(a) $\mathrm{IL}-1 \beta$

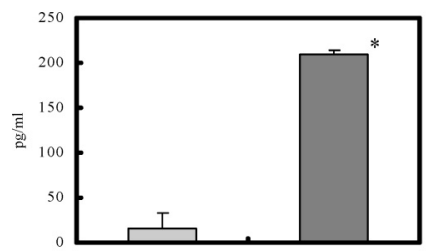

(c) IL-6

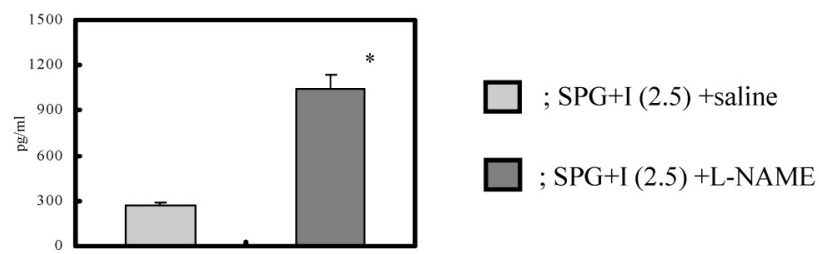

Fig. 5. Effect of L-NAME on Cytokine Levels of PEC

SPG $(100 \mu \mathrm{g} /$ mouse $)$ was administered i.p. 3 times on day-5, -3 , and -1 . Indomethacin (IND; $2.5 \mathrm{mg} / \mathrm{kg}$ ) was administered p.o. and L-NAME $(10 \mathrm{mg} / \mathrm{kg}$ ) was administered i.p. once a day from day 0 to 6 . Peritoneal exuded cells (PEC) were prepared on day 6 and incubated for $24 \mathrm{~h}$ at $37^{\circ} \mathrm{C}$ in $5 \% \mathrm{CO}_{2}$. (a) IL- $1 \beta$, (b) TNF- $\alpha$, (c) IL-6 production was measured by ELISA. Results are shown as the mean \pm S.D. The significance was evaluated with Student's $t$-test. $* p<0.05$.

enhanced production of IL- $1 \beta$, IL- 6 , and TNF- $\alpha$ and the number of PEC was significantly increased on day 6 (Fig. 6 ). Additionally, as shown in Fig. 6b, nitrite synthesis by PEC from L-NAME-administered mice was also enhanced. However, L-NAME had no effect on nitrite levels in sera (data not shown). All of these results suggest that the inhibition of NO production augmented the inflammatory response of leukocytes in SPG/IND-treated mice.

Effect of L-NAME on SPG/IND-Induced Hepatic Damage To examine the effect of L-NAME on hepatic damage, we assessed GOT and GPT levels in sera. SPG was administered intraperitoneally to mice on day- $-5,-3$, and -1 . IND was administered orally and L-NAME or saline was injected intraperitoneally daily from day 0 to 7 . On day 7 , groups of mice were sacrificed and serum samples were collected. As shown in Fig. 7, the release of GOT and GPT was increased in mice treated with the combination of L-NAME and SPG/IND. It was found that the effect of L-NAME in SPG/IND-treated mice contributed to liver dysfunction. 
(a)
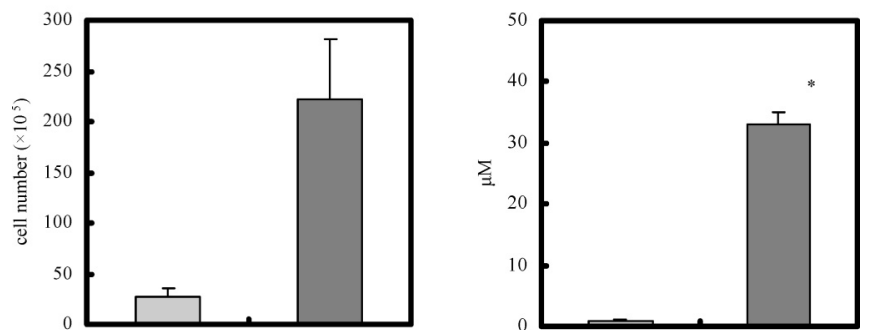

口; $\mathrm{SPG}+\mathrm{I}(2.5)+$ saline

Fig. 6. Effect of L-NAME on Cell Number and Nitrite Production in PEC SPG $(100 \mu \mathrm{g} / \mathrm{mouse})$ was administered i.p. 3 times on day-5, -3 , and -1 . Indomethacin (IND; $2.5 \mathrm{mg} / \mathrm{kg}$ ) was administered p.o. and L-NAME $(10 \mathrm{mg} / \mathrm{kg})$ was administered i.p. once a day from day 0 to 6 . On day 6 , mice were sacrificed and numbers of peritoneal exuded cells (PEC) were measured. PEC were prepared on day 6 and incubated for $24 \mathrm{~h}$ at $37^{\circ} \mathrm{C}$ in $5 \% \mathrm{CO}_{2}$. Nitrite production was measured with Griess reagent. Results are shown as the mean \pm S.D. The significance was evaluated with Student's $t$-test. $* p<0.05$. (a) cell number of PEC, (b) nitrite production.

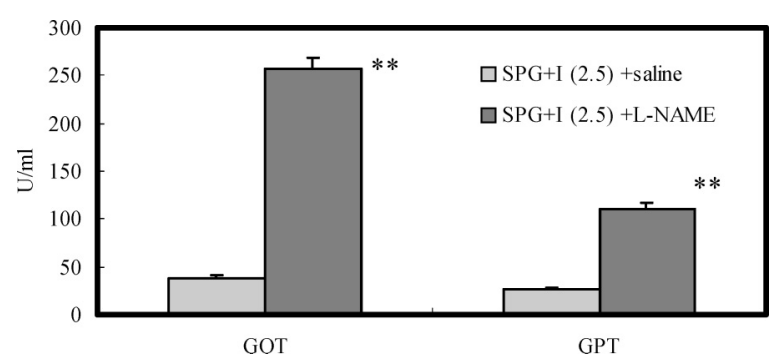

Fig. 7. Effect of L-NAME on SPG/IND-Induced GOT or GPT Release

SPG $(100 \mu \mathrm{g} /$ mouse) was administered i.p. 3 times on day-5, -3 , and -1 . Indomethacin (IND; $2.5 \mathrm{mg} / \mathrm{kg}$ ) was administered p.o. and L-NAME $(10 \mathrm{mg} / \mathrm{kg})$ was administered i.p. once a day from day 0 to 7 . Sera were prepared on day 7. GOT and GPT levels were measured with a GO and GP transaminase kit. Results are shown as the mean \pm S.D. The significance was evaluated with Student's $t$-test. $* * p<0.01$

TNF- $\alpha$ and IL-6 Concentrations in Sera of SPG/IND/L-NAME-Administered Mice after LPS Treatment To better understand the underlying mechanism, we investigated the effect of L-NAME on sensitivity to LPS in SPG/IND-administered mice. SPG was injected intraperitoneally on day $-5,-3$, and -1 . IND was administered orally and L-NAME or saline intraperitoneally on day 0 and day 1 . To assess the sensitivity, LPS ( $1 \mu \mathrm{g} /$ mouse) was administered intravenously on day 1 . Then, sera were collected at $1,1.5$, and $2 \mathrm{~h}$ after the LPS treatment. As shown in Fig. 8, TNF- $\alpha$ and IL-6 levels were significantly enhanced by SPG/IND-LNAME compared with SPG/IND-saline. These findings suggested that inhibition of NO production increases sensitivity to LPS.

\section{DISCUSSION}

We have previously shown that a combination of $\beta$-glucan and NSAIDs was lethal to mice. ${ }^{20-23)}$ This model induces an endogenous sepsis in mice using two drugs, IND and SPG, without administering LPS directly. In this study, we examined the role of NO in sepsis using this model. Generally, sepsis induces the expression of iNOS leading to the production of large amounts of NO. Several reports suggest that the NO produced by iNOS is detrimental. However, the knock out of iNOS in mice enhanced viral infection. ${ }^{24)}$ In fact, NO

(a)

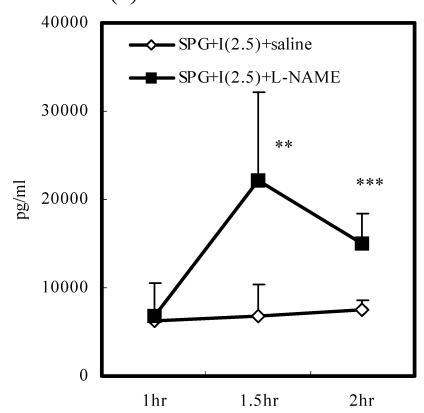

(b)

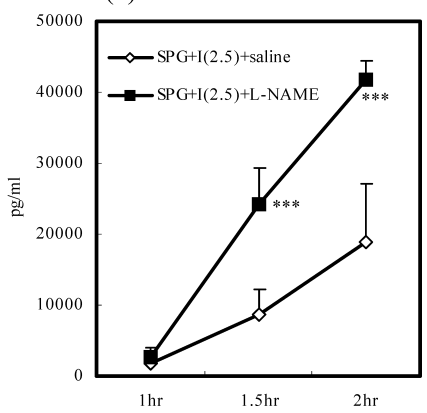

Fig. 8. TNF- $\alpha$ and IL-6 Concentrations in Sera of SPG/IND/L-NAMEAdministered Mice after LPS Treatment

SPG $(100 \mu \mathrm{g} /$ mouse) was administered i.p. 3 times on day-5, -3 , and -1 . Indomethacin (IND; $2.5 \mathrm{mg} / \mathrm{kg}$ ) was administered p.o. and L-NAME $(10 \mathrm{mg} / \mathrm{kg})$ was administered i.p. once a day on day 0 and day 1 . LPS ( $1 \mu \mathrm{g} /$ mouse) was administered i.v. After $1,1.5$, and $2 \mathrm{~h}$ of LPS treatment, sera were prepared. TNF- $\alpha$ and IL- 6 concentrations were measured by ELISA. Results are shown as the mean \pm S.D. The significance was evaluated with Student's $t$-test relative to the SPG/IND/saline-group. $* * p<0.01$, $* * * p<0.001$. (a) TNF- $\alpha$, (b) IL-6.

has dual roles in sepsis. ${ }^{13,14)}$ The difference in the model of sepsis used may be one explanation for why the effect of NO on the pathosis differed.

In the first experiment, we examined the concentration of nitrite in PEC cultures (Fig. 1). SPG and IND-administered mice produced significant amounts of nitrite but IND-administered mice did not. We have previously reported that SPG did not affect the production of $\mathrm{NO}$ in vivo or in vitro. ${ }^{25,26)} \mathrm{In}$ the present study, we found that the combination of SPG and IND enhanced NO production.

We examined the effect of NO production on mortality in this model using NOS inhibitors. The inhibition of NO enhanced the toxicity (Figs. 2-4). Although lethal activity was induced by the administration of IND $(5 \mathrm{mg} / \mathrm{kg})$ and LNAME independent of SPG, as shown in Fig. 3, by the administration of lower concentration of IND $(2.5 \mathrm{mg} / \mathrm{kg})$, the mortality was only significant in SPG co-treated mice. Inhibition of iNOS did not enhance the lethality of saline/IND $(5 \mathrm{mg} / \mathrm{kg})$ administered mice (Fig. 4). All these data strongly suggested NO shows protective effect in SPG/IND-induced septic model.

NO plays a crucial role in the gastrointestinal tract. ${ }^{27)}$ eNOS is an enzyme which mostly localizes to vascular endothelial cells and produces NO all the time. In a recent study, it was found that this enzyme is also expressed in gastrointestinal mucosal cells. ${ }^{28)}$ The NO produced by eNOS affects not only vasohypotonic actions but also the gastrointestinal microcirculation-mediated suppression of platelet aggregation and neutrophil-endothelial cell interaction. ${ }^{29,30)}$ In addition, NO plays a critical role in the maintenance of mucosal homeostasis as a regulatory factor of acid and mucus secretion. Tanaka et al. reported that IND and L-NAME administration aggravated the mucosal injury and bacterial translocation in rats. ${ }^{31)}$ That is, it was also suggested that IND-derived gastrointestinal injury was elicited by inhibiting NO production in mice and NO produced by both eNOS and iNOS is an important factor for SPG and IND administered mice.

Significant numbers of bacteria were detected in several organs of the mice administered SPG, IND and L-NAME (Table 1). This indicates that our model reflects the clinical situation whereby a sudden propagation of bacteria leads to 
an unexpected lethal toxicity. However, the origin of the bacteria detected in this model is not clear. The gastrointestinal, respiratory and cutaneous mucosa act as barriers. Ordinarily, the mucosa consists of epithelial cells. Therefore, it distinguishes internal from external bodies preventing bacteria from invading. However, a disruption of barrier function induces bacterial invasion and leads to inflammation. Generally, the main side effect of NSAIDs is gastroduodenal injury due to a suppression of prostaglandin synthesis. ${ }^{32-34)}$ So, in this model, the bacteria that spread throughout the body may be derived from enterobacteria.

The mechanism of SPG/IND-mediated lethality is yet to be clarified. However, in this study we found that mice given SPG and a less lethal dose of IND died following the administration of a NOS inhibitor, L-NAME. L-NAME has two roles in sepsis, i.e., to eNOS and to iNOS. Inhibition of the production of $\mathrm{NO}$ by eNOS affects mucosal function and the regulation of blennorrhagia and provokes mucosal damage. This damage leads to enterobacterial translocation. Fundamentally, the NO produced by iNOS has bactericidal activity but iNOS is inhibited by administration of L-NAME and so the activity is reduced. As a result, the bacteria spread to various organs, leading to systemic inflammatory response syndrome. The production of NO, therefore, has a protective effect in $\beta$-glucan/IND-induced sepsis.

iNOS and eNOS have many activities and roles are complex. Recently, it is reported that eNOS relates to iNOS expression and not only iNOS but also eNOS has a proinflammatory role. ${ }^{35)} \mathrm{NO}$ has an effective or detrimental effect in sepsis. In this model, however, the balance of effects seems to be a trend effectively. There are some reports about the effect of NOS inhibitors on sepsis patients. ${ }^{10,12,36)}$ However, it's difficult to determine whether NOS inhibitors affect morbidity and mortality because of few studies. Moreover, many of the experimental animals don't completely reflect the pathology on that of sepsis patients. To clarify the mechanism of sepsis, not only about the role of $\mathrm{NO}$, it would be important to develop and analyze the sepsis model more clinically and molecularly.

\section{REFERENCES}

1) Nathan C. F., Hibbs J. B., Curr. Opin. Immunol., 3, 65-70 (1991).

2) Oswald I. P., James S. L., Methods, 10, 8-14 (1996).

3) Titheradge M. A., Biochim. Biophys. Acta, 1411, 437-455 (1999).

4) Kuemmerle J. F., Am. J. Physiol., 274, 178-185 (1998).

5) Chen J. Y., Chiu J. H., Chen H. L., Chen T. W., Yang W. C., Yang A.
H., Perit. Dial. Int., 20, $772-777$ (2000).

6) Victor V. M., Rocha M., De la Fuente M., Int. Immunopharmacol., 4, 327-347 (2004).

7) Lissac J., Kayal S., Bull. Acad. Natl. Med., 179, 1671-1688 (1995).

8) Landry D. W., Oliver J. A., N. Engl. J. Med., 23, 588-595 (2001).

9) Kilbourn R. G., Gross S. S., Jubran A., Adams J., Griffith O. W., Levi R., Lodato R. F., Proc. Natl. Acad. Sci. U.S.A., 87, 3629-3632 (1990).

10) Lorente J. A., Landin L., De Pablo R., Renes E., Liste D., Crit. Care Med., 21, 1287-1295 (1993).

11) Evans T., Carpenter A., Silva A., Cohen J., J. Infect. Dis., 169, 343 349 (1994).

12) Petros A., Bennett D., Vallance P., Lancet, 338, 1557-1558 (1991).

13) Harbrecht B. G., Billiar T. R., Stadler J., Demetris A. J., Ochoa J. B., Curran R. D., Simmons R. L., Crit. Care Med., 20, 1568-1574 (1992).

14) Kilbourn R. G., Szabo C., Traber D. L., Shock, 7, 235-246 (1997).

15) Yadomae T., Jpn. J. Med. Mycol., 33, 267-277 (1992).

16) Adachi Y., Ishii T., Ikeda Y., Hoshino A., Tamura H., Aketagawa J., Tanaka S., Ohno N., Infect. Immun., 72, 4159-4171 (2004).

17) Harada T., Miura N. N., Adachi Y., Nakajima M., Yadomae T., Ohno N., J. Interferon Cytokine Res., 24, 478-489 (2004).

18) Ishibashi K., Miura N. N., Adachi Y., Tamura H., Tanaka S., Ohno N., FEMS Immunol. Med. Microbiol., 42, 155-166 (2004).

19) Ohno N., Jpn. J. Infect. Dis., 57, 9-10 (2004).

20) Yoshioka S., Ohno N., Miura T., Adachi Y., Yadomae T., FEMS Immunol. Med. Microbiol., 21, 171-179 (1998).

21) Takahashi H., Ohno N., Adachi Y., Yadomae T., FEMS Immunol. Med. Microbiol., 31, 1-14 (2001).

22) Moriya K., Ohno N., Miura N. N., Adachi Y., Yadomae T., Drug Dev. Res., 55, 139-148 (2002).

23) Moriya K., Miura N. N., Adachi Y., Ohno N., Biol. Pharm. Bull., 25, 816 -822 (2002).

24) Nathan C., J. Clin. Invest., 100, 2417-2423, (1997).

25) Ohno N., Miura N. N., Chiba N., Adachi Y., Yadomae T., Biol. Pharm. Bull., 18, 1242-1247 (1995).

26) Hashimoto T., Ohno N., Adachi Y., Yadomae T., Biol. Pharm. Bull., 20, 1006-1009 (1997).

27) Vallance B. A., Dijkstra G., Qiu B., van der Waaij L. A., van Goor H., Jansen P. L., Mashimo H., Collins S. M., Am. J. Physiol. Gastrointest. Liver Physiol., 287, 865-874 (2004).

28) Chen Y. M., Qian Z. M., Zhang J., Chang Y. Z., Duan X. L., World J. Gastroenterol., 8, 537-539 (2002).

29) Radomski M. W., Palmer R. M., Moncada S., Lancet, 2, 1057-1058 (1987).

30) Kubes P., Suzuki M., Granger D. N., Proc. Natl. Acad. Sci. U.S.A., 88, 4651-4655 (1991).

31) Tanaka A., Mizoguchi H., Kunikata T., Miyazawa T., Takeuchi K., J. Physiol. Paris., 95, 35-41 (2001).

32) Scarpignato C., Dig. Dis., 13, 9-39 (1995).

33) Wright V., Br. J. Rheumatol., 34, $2-4$ (1995).

34) Rainsford K. D., Am. J. Med., 107, 27-36 (1999).

35) Connelly L., Madhani M., Hobbs A., J. Biol. Chem., 280, 10040 10046 (2005).

36) Petros A., Lamb G., Leone A., Moncada S., Bennett D., Vallance P., Cardiovasc. Res., 28, 34-39 (1994). 